\title{
Education for Sustainable Development: Implications for University Managers, Government and the Private Sector in Uganda
}

\author{
Baligidde H. Samuel \& Ssempebwa Jude
}

Taking the case of Makerere University, this study delved into the rationale underlying university participation in development planning and steps that universities could take to enhance their partnership with government and the private sector. Data were collected from 381 respondents, who included academic staff, managers and student leaders at the University. The respondents suggested that the University should help the government in drawing and implementing development plans, adding that this could provide a means of overcoming its antagonistic relationship with the government. Regarding the steps the University could take to help government, they suggested that it could tailor its research and teaching programs to complement the latter's efforts; restrain from partisan politics; include more government representatives on its committees; and mobilize private sector support for its programmes. Regarding government's role in harnessing the University's contribution to national development, the respondents suggested that government should respect the University's autonomy as well as its members' academic and democratic freedom. Finally, the respondents argued for university-private-sector-alignment, urging that the University partners with relevant private sector actors to design curricula and research programmes that, respectively, produce graduates and information that are demanded in the contemporary market.

Key words: Higher education; Relevance; University management

\section{Introduction}

The changes being experienced in universities have implications for the role of university education in sustainable development. As the number of universities increases and universities are transformed, from government-controlled-bureaucracies to quasi-corporate organizations, the development component of academic roles is expanding. Changes are taking place in higher education managers' responsibilities, as the managers become more significant players in facilitating teaching and learning that contributes to sustainable development and realize that university education should be re-oriented towards national development. However, there has always been a controversy over the alignment between education and development. While some scholars argue that national development has always preceded educational advancement, others maintain that this need not be the case. Incidentally, the philosophers along whose ideas education systems have been designed defined education in accordance with their philosophy of life, with the result that conflicting perspectives on what education is for emerged, thereby deepening the controversy. This paper reports the findings of a study that attempted to extend knowledge on

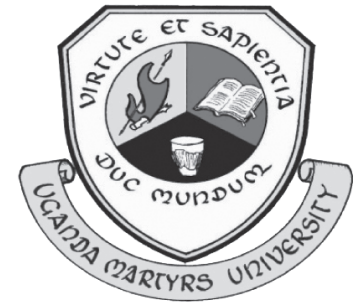

Journal of Science and Sustainable Development Copyright (C) 2009 Uganda Martyrs University ISSN: 2070-1748; Vol 2 (1): 41-45 www.umu.ac.ug 
this controversy, grounded on the proposition that the way a society perceives and interprets the aim and nature of education determines its responses to education and, subsequently, the characteristics of that society's education system. The proposition is examined in light of its implications for university managers and sustainable national development.

According to Ball (1977), education influences the process of socialization and societal development. This is especially true at the university level. For example, the decentralization of higher education may lead to a situation in which universities promote regional, or local, loyalties and reinforce ethnic or religious attitudes (Mugagga, 2006; Kasibante, 2001; Kaire, 2003). Aggarwal (1985) states that the concept of education is like a diamond, which appears to be of a different colour when seen from a different angle, the inference being that different individuals, groups and societies perceive the role of university education in development differently. Besides, education is itself dynamic, so perceptions of its role in national development change whenever there are changes in its characteristics or in the society in which it is delivered. In other words, university education is intrinsically dialectical (Bullock and Stallybrass, 1977), meaning that it should change whenever societal needs change.

Through the provision of skills and shaping of attitudes that are designed to enhance competence, education plays a major role in national development (Forojalla, 1993). Indeed, Ssentamu (2006) notes that, since the $12^{\text {th }}$ century, the concept, utility and relevance of universities have evolved alongside the economic, social, political and technological transformations of society. This means that the way a society perceives the role of education determines that society's responses to education and, subsequently, the development-mindedness of the education system that emerges. Whereas there is significant congruence on this, the problem is that politicians commonly manipulate societal goals for their egocentric motives. Often, therefore, politicians' perceptions of the role of university education in national development differ from those of the wider society. For example, politicians sometimes perceive university education as an instrument of mobilization for partisan political interests (Mamdani, 1994); and since educational institutions must operate under the superstructure of government, let alone the political environment, divergence in perceptions of the role of university education is one of the challenges faced by university managers because it causes antagonism between the state, the private sector and the university.

Leadership has been recognized as vitally important in surmounting this challenge (Nkata, 2005). This means that university managers need to extend their range of conceptual insight into university leadership for sustainable development. Nonetheless, the market-driven reforms that have shaped the development of university education over the last three decades cannot enhance national development, since they relegate educational ideals (Olweny, 2008; Ssesanga, 2004; Mamdani, 2007). In view of this consideration, the role of university education in national development vis-à-vis that of government and the private sector becomes complicated, furthering the controversy on what university education is for. Taking the case of Makerere University, therefore, a recent study delved into the rationale of university participation in national development planning; steps that universities could take to enhance their partnership with government and the private sector in the processes of development planning; and the things that governments could do to enhance the participation of their universities in national development planning. This paper presents the findings of the study.

\section{Method}

The study was carried out at Makerere University. Data were collected, using questionnaires, from a sample of 381 respondents. The sample size was based on Krejcie and Morgan (1970)'s sample size estimation table and the respondents included academic staff, senior administrators and student leaders at the University. Notwithstanding the variation among them, across the various categories of respondents, the questions in the questionnaires elicited the respondents' views on the rationale underlying advocacy 
for university participation in developing national development plans and implementing them; steps that universities could take to enhance their partnership with government and the private sector in the processes of drawing and implementing national development plans; and the things that governments could do to enhance the participation of their universities in the planning and implementation of national development efforts. The data were analyzed using frequency counts and percentages, to highlight the most dominant views and, subsequently, draw conclusions.

\section{Findings}

Majority $(84 \%, n=318)$ of the respondents suggested that Makerere University should help the government in drawing national development plans, because it has the technical competence to do so. Moreover, some $(9 \%)$ of the respondents expressed the view that the University's involvement in national development planning could provide a means of overcoming its antagonistic relationship with the government. Regarding the steps the University could take to enhance its partnership with government in the processes of development planning, the respondents suggested that the University could complement the latter's development efforts (32\%); and restrain from partisan politics (33\%). The respondents suggested that the University ought to include more government officials on its committees, to improve its relations with the government. This, the respondents argued, would enhance mutual trust and, subsequently, enhance the integration of the University's and government's efforts. In addition, some of the respondents suggested that the University should mobilize private sector support for its policies and programmes, rationalizing that public goodwill for the University's programs would attract government to support them. Regarding government's role in harnessing the University's contribution to national development, the respondents suggested that government should respect the University's autonomy, by desisting from politicizing its leadership, through appointing partisan persons to its top management. It was also suggested that government respects the academic and democratic freedom of the members of the university community, appreciative of the fact that, even without taking part in partisan politics, universities generate political ideas, and can influence political choice, since they are a microcosm of the electorate. Finally, majority of the respondents argued for university-private-sectoralignment, urging that the University partners with relevant private sector actors to design innovative curricula and research projects that, respectively, produce graduates and knowledge that are demanded in the contemporary market.

\section{Discussion and Conclusions}

The findings of the study suggest that although universities can be seen to be serving multiple purposes, in the context of the discourse on the need for sustainable development, university education is for development. Therefore, university managers ought to understand that their universities can no longer afford to be 'ivory towers', and drift along incognizant of the needs, and efforts, of the government and private sectors. This is corroborated by Warakaulle (2004). Rather, the universities should integrate the efforts of the government and private sectors, an effort that the managers of the universities should spearhead. This would secure advantages for the universities, such as better institutional funding and production of graduates that, on account of their universities' alignment with government and the private sector, are readily employable upon graduation. This means that university managers should look at the work of their universities in terms of relevant development needs, just as is suggested by Nkata (2005). Thus, university managers should depart from the colonialist African university, which was structurally and culturally modelled along Oxbridge with little, if any, consideration for its African location (Todaro, 1998; Hagan, 1994; Mamdani, 1994; Mazrui, 1994). The findings of the study also indicate that, nonetheless, government should not take advantage of its partnership with the universities to promote egocentric political motives. This is because development plans that unduly work for the politicians' manifestos are bound to be undermined by a significant section of 


\section{Journal of Science and Sustainable Development \|}

the university community, with the consequence of causing antagonism yet, for university education to contribute to sustainable development, university-government relations need to be complementary rather than confrontational.

The respondents made an indication of their wish to develop, and maintain, partnerships with the private sector. This finding introduces a new dimension in the debate on the relevance of African higher education to the continent's development needs. In contrast to the famous criticism that African universities are irresponsive to their societies' development needs (see, for example, Ssekamwa, 1999; Rwamutega, 2004; Al- Samarrai et al., 2003; Mugaju, 2004; Mayanja, 2002; Maicibi, 2003; Musoke, 2004; Muyingo, 2005), the study indicates that Makerere University is inviting partnership with the private sector. This means that private sector actors should declare their knowledge and skill needs to the University and avail themselves to partner with the University in designing, funding and implementing the research efforts and curricula innovations that may be necessitated to meet these needs. It may be noted that such partnership would provide for sustainable university-private-sector responsiveness, since needs would be identified as they arise and solutions devised as such. Through creating value for the private sector, and facilitating the translation of research into products, such partnership could

also earn revenue for the University, thereby reducing dependency on government and donor funding (and undermine of autonomy due to the dependency) let alone reduce the adoption of unsustainable, in principle maladaptive, strategies of coping with under funding that relegate the ideals of university education (Olweny, 2008; Ssesanga, 2004; Mamdani, 2007).

\section{References}

Aggarwal, J. C., 1985. Theory and principles of Education. New Delhi: Vikas Publishing House PVT.

Al-Samarrai, Samer and Paul, Bennell, 2003. Where has all the education gone in Africa? Employment outcomes among secondary school and university leavers. Brighton: Institute of Development Studies at the University of Sussex.

Ball, A. R., 1977. Modern politics and government. London: The Macmillan Press.

Bullock, A. and Stallybrass, 1977. The Fontana Dictionary of modern thought. New York: Fountain / Collins.

Forojalla, S. B., 1993. Educational planning for development. London: The Macmillan Press.

Hagan, P. G., 1994. Academic freedom and national responsibility in an African state: Ghana. In: M. Mamdani and M. Diouf, eds. 1994. Academic freedom in Africa. Dakar: CODESRIA.

Kasibante, I. F., 2004. Catholic school mission and character education report 2004. Entebbe: Marianum Press Kisubi.

Krejcie, R. and Morgan, D. W., 1970. Determining Sample Size for Research Activities, Educational and Psychological Measurement. London: Sage Publications.

Maicibi, N. A., 2003. Pertinent issues in employees management. Kampala: MPK Graphics (U) Ltd.

Mamdani, M., 2007. Scholars in the marketplace: the dilemmas of neo-liberal reform at Makerere University, 19892005. Kampala: Fountain Publishers.

Mamdani, M., 1994. The quest for academic freedom. In: M. Mamdani and M. Diouf, eds. 1994. Academic freedom in Africa. Dakar: CODESRIA.

Mayanja, M. K., 2002. Graduate employment: investing in the service mandate of the African university. Paper presented to the symposium on the African University in the $21^{\text {st }}$ Century. Dakar, Senegal, 2527 April, 2002. [Online] Available at: http://www.codesria.org/Links/conferences/universities/ Muhammad_Mayanja.pdf 
Mazrui, A. A., 1994. The impact of global changes on academic freedom in Africa: a preliminary assessment. In: M. Mamdani and M. Diouf, eds. 1994. Academic freedom in Africa. Dakar: CODESRIA.

Mugagga, A. M., 2006. The Philosophy behind the university curriculum in Uganda. In: National Education Graduate Students Conference Proceedings. Makerere University School of Education.

Mugaju, J., 2004. A model university for Uganda. The Uganda Higher Education Review: Journal of the National Council for Higher Education, 1 (1).

Musoke, A., 2004. Parliament now liberated, says M7. The New vision, 24 Dec. pp. 1-2.

Muyingo, A., 2005. We need to overhaul our entire education system to develop. The Monitor, 19 Jan. p.5.

Nkata, J. L., 2005. Emergent issues in education management in the Developing Countries in the $21^{\text {st }}$ century. Kampala: Masah Publishers Ltd.

Olweny, C. L. M., 2008. Vice Chancellor's concept for the proposed school [of Diplomacy and International Studies]. In: Final Report of the Task Force on the establishment of the East African School of Diplomacy and International Studies at Uganda Martyrs University. (Uganda Martyrs University report). 2008.

Rwamutega, T., 2004. University education needs overhauling. The New vision, 1 December, op-ed.

Ssekamwa, J. C., 1999. Lectures in History of Education. Kampala: Makerere University School of Education.

Ssentamu, P. N., 2006. Towards a standard university curriculum in Uganda. In: National Education Graduate Students Conference Proceedings. Makerere University School of Education.

Ssesanga, K., 2004. Ethical issues in the marketisation of education: the case for social justice and market-oriented reforms in Uganda's higher education. Makerere Journal of Higher Education, 1 (1).

Todaro, M. P., 1998. Economics for a developing world: an introduction to principles, problems and policies for development. $3^{\text {rd }}$ ed. $6^{\text {th }}$ impression. USA: Longman.

Warakaulle, H. M. N., 2004. External influences on university governance. [Online] Available at: www.unesco.org [Accessed 10 May 2005].

\section{ABOUT THE AUTHORS}

BALIGIDDE H. SAMUEL is the Director, East African School of Diplomacy, Governance and International Studies, Uganda Martyrs University while SSEMPEBWA JUDE is Editor at Uganda Martyrs University Research Directorate. For correspondence on this article please contact: P. O. Box 7071, Kampala, Uganda. E-mail: sbaligidde@umu.ac.ug or jssempebwa@umu.ac.ug 
